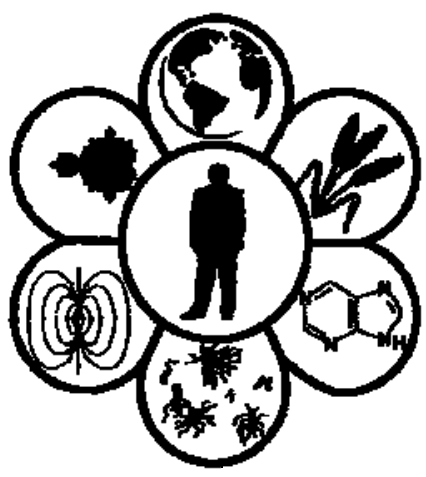

Вісник Дніпропетровського університету. Біологія, медицина Vìsnik Dnìpropetrovs'kogo unìversitetu. Seriâ Bìologìâ, medicina

Visnyk of Dnipropetrovsk University. Biology, medicine

Vìsn. Dnìpropetr. Unìv. Ser. Bìol. Med. 2016. 7(1), 3-7.

doi:10.15421/021601

ISSN 2310-4155 print

ISSN 2312-7295 online

www.medicine.dp.ua

УДК 577.1:612.015

\title{
Динаміка активності амінотрансфераз сироватки крові щурів за оксидаційного стресу та дії ліпосомального препарату
}

\begin{abstract}
M.I. Харів
Львівський національний університет ветеринарної медиџини та біотехнологій імені С.З. Гжсицького, Львів, Україна

Наведено результати досліджень впливу комплексного ліпосомального препарату на динаміку показників активності амінотрансфераз організму щурів за змодельованого оксидаційного стресу, викликаного застосуванням тетрахлорметану. Внутрішньом'язове уведення щурам дослідних груп 50\% тетрахлоретану у дозі 0,25 мл на 100 г маси тіла тварини спричиняє антигенне навантаження на організм, викликає підвищення проникності клітинних оболонок гепатоцитів та мітохондріальних мембран. Про це свідчить зростання активності амінотрансфераз у сироватці крові протягом усього періоду досліджень. На другу добу досліджень відмічали підвищення АсАТ у 2,5 раза, АлАТ - удвічі, а коефіцієнта АсАТ/АлАТ - на 30\% порівняно 3 контролем. На 14-ту добу досліджень активність даних показників залишалася вищою порівняно з показниками контрольної групи тварин: АсАТ і АлАТ відповідно на 93\% та 81\%, показник коефіціснта був вищим і становив 2,89 $\pm 0,05$ проти контролю 2,72 $\pm 0,04$ (на 9\% вище). Для нормалізації проникності клітинних оболонок гепатоцитів та мітохондріальних мембран за оксидаційного стресу доцільно застосовувати ліпосомальний препарат, який у своєму складі містить бутафосфан, інтерферон, розторопшу плямисту та вітаміни. У разі застосування ліпосомального препарату щурам, за оксидаційного стресу, у крові настає нормалізація активності ензимів переамінування (нормалізація активності АсАТ і АлАТ сироватки крові). На 14-ту добу досліду показники ензиматичної активності амінотрансфераз у крові дослідних щурів коливалися в межах фізіологічних величин, що вказує на нормалізацію проникності клітинних оболонок гепатоцитів та мітохондріальних мембран за оксидаційного стресу та за дії ліпосомального препарату.
\end{abstract}

Ключові слова: аспартат-амінотрансфераза; аланін-амінотрансфераза; печінка; бутафосфан; інтерферон; розторопша плямиста

\section{Dynamics of indices of aminotransferase activity in the blood serum of rats under conditions of oxidative stress and effect of liposomal medicinal product}

\author{
M. Khariv
}

\section{Lviv National University of Veterinary Medicine and Biotechnologies named after S.Z. Gzhytskyj, Lviv, Ukraine}

The article presents the results of testing the effect of a developed complex liposomal medicinal product on the dynamics of aminotransferase activity indices of the organisms of rats under conditions of designed oxidative stress induced by means of carbon tetrachloride application. It was demonstrated that intramuscular administration to rats from the tested groups of $50 \%$ tetrachloroethene at the dose of $0.25 \mathrm{ml}$ to $100 \mathrm{~g}$ of body weight causes antigen loading on the organism and increase in the cell membrane penetrability of hepatocytes and mitochondrial membranes. This was demonstrated by increase in activity of aminotransferase in the blood serum during the whole period of the experiment. On the second day of the test aspartate transaminase increased 2.5 times, alanine aminotransferase twice and the coefficient of AST/ALT by $30 \%$ in comparison with the control group. On the 14th day of the test the activity of these indices was higher compared to the indices in the control group, AST and ALT by $93 \%$ and $81 \%$ respectively, the coefficient index was higher and was equal to $2.89 \pm 0.05$ in comparison to the index for the control $(2.72 \pm 0.04)$, that is $9 \%$ higher than the control indices. In order to normalize cell membrane penetrability of hepatocytes and mitochondrial membranes under conditions of oxidative stress, it is useful to apply a liposomal medicinal product containing butafosfan, interferon, cardus marianus and vitamins. The application of the liposomal medicinal product to rats under the experimental conditions of oxidative stress caused the normalization of enzyme activity of reamidation in the blood, namely normalization of AST and ALT activity in the blood serum. On the 14th day the indices of enzyme activity of aminotransferase in the blood

Львівський наџіональний університет ветеринарної медиџини та біотехнологій імені С.3. Гжищького, вул. Пекарська, 50, Львів, 79010, Україна

Lviv National University of Veterinary Medicine and Biotechnologies named after S.Z. Gzhytskyj, 50, Pekarska Str., Lviv, 79010, Ukraine Tel.: +38-067-483-04-87.E-mail: Chariv_II@ukr.net 
of the tested rats fluctuated within the physiological values that demonstrate the normalization of cell membrane penetrability of hepatocytes and mitochondrial membranes under conditions of oxidative stress and the liposomal effect of the medicinal product.

Keywords: oxidative stress; alanine-aminotransferase; aspartate-aminotransferase; rat's organism; liposomal preparation; butafosfan; interferon; milk thistle

\section{Вступ}

Найбільша проблема у тваринництві нині - зниження імунобіологічної реактивності у постнатальний період розвитку та дія антропогенних чинників, які дестабілізують метаболічні процеси в організмі, спричинюють зниження природної резистентності, пригнічують протеїнсинтезувальну функцію печінки, впливають на ензимну активність амінотрансфераз. Відповідно до сучасних досліджень установлено, що стійкість організму тварин до захворювань забезпечує імунна система, головна функція якої - розпізнавання та знешкодження чужорідних речовин для підтримання стабільності генетичного гомеостазу організму. Велику роль у цих процесах відіграє печінка, де синтезуються протеїни, особливо їх глобулінові фракції. У печінці відбувається також синтез ензимів амінотрансфераз, які підтримують загальний гомеостаз в організмі. Серед багатьох факторів, що негативно впливають на імунну систему, протеїнсинтезувальну та ензимну функцію печінки тварин, важливе місце посідають різні імунодепресанти, які пригнічують вищезгадані функції (Kornyat et al., 2015). За цих умов розвивається імунодефіцитний стан. Власне тому організм може уражатися вторинною бактеріальною або вірусною інфекціями (Devanto et al., 2002; Meyers et al., 2003). Для підвищення адаптаційної здатності та імунобіологічної реактивності організму, посилення протеїнсинтезувальної та ензиматичної функції тварин останніми роками 3 успіхом застосовують нові комплексні препарати (Liu and Finley, 2005; Rababah et al., 2005). Окремі автори встановили стимулювальний вплив бутафосфану, розторопші, вітамінів на імунну, антиоксидантну та гепатопротекторну активність у тварин. Однак метаболічна дія цих препаратів на функцію печінки та імунну систему на даний час у науковій літературі висвітлена недостатньо.

Наведене вище обгрунтовує доцільність дослідження впливу комплексного ліпосомального препарату (до складу якого входять бутафосфан, інтерферон, розторопша та вітаміни) на формування імунітету та забезпечення високої природної резистентності у тварин, їх впливу на функцію печінки, позитивного впливу на обмін речовин у їх організмі, підвищення росту та збереженості поголів'я.

\section{Матеріал і методи досліджень}

Дослідження проводили на молодих білих лабораторних щурах-самцях лінії Вістар масою тіла 180-200 г, яких утримували у стандартних умовах інститутського віварію Державного науково-дослідного контрольного інституту ветеринарних препаратів і кормових добавок. Протягом усього експерименту щурів утримували на збалансованому раціоні, що містив усі необхідні компоненти. Питну воду тварини отримували без обмежень із скляних напувалок об'ємом 0,2 літра.
Сформовано три групи щурів по 20 тварин у кожній. Щурам першої та другої дослідних груп для отримання оксидаційного стресу на першу та третю добу досліджень уводили внутрішньом'язово 50\% тетрахлорметан у дозі 0,25 мл на 100 г маси тіла тварини, яку визначали їх щоденним зважуванням, що дозволило чітко дотримуватися досліджуваної дози препарату протягом усього експерименту. Тварини контрольної групи отримували аналогічний об'єм води для ін'єкцій. Теоретично можливий вплив води на аналізовані гематологічні та біохімічні показники був однаковим як на дослідні, так i на контрольну групу тварин. Другій дослідній групі тварин на першу та третю добу досліджень за годину після уведення тетрахлорметану додатково уводили ліпосомальний препарат (2 мл на тварину). До складу даного препарату входять такі речовини: бутафосфан, інтерферон, розторопша ін'єкційна та вітаміни $\mathrm{A}, \mathrm{E}$ i $\mathrm{D}_{3}$. Кров для біохімічних та гематологічних досліджень забирали під ефірним наркозом 3 яремної вени на другу, п'яту, десяту та п'ятнадцяту добу експерименту.

Усі маніпуляції з тваринами проводили відповідно до Європейської конвенції про захист хребетних тварин, які використовуються для експериментальних і наукових цілей (Страсбург, 1986 р.).

У сироватці крові за допомогою стандартних наборів реактивів фірми Simko Ltd (Чехія) визначали активність аспартат-амінотрансферази (АсАТ) (КФ 2.6.1.1) та аланін-амінотрансферази (АлАТ) (КФ 2.6.1.2) уніфікованим динітрофенілгідразиновим методом Райтмана - Френкеля. Метод базується на тому, що після додавання до сироватки крові 2,4-дифенілгідразинового реактиву відбувається переамінування, утворення глутамінової та піровиноградної кислот (АсАТ) або глутамінової та щавлевооцтової кислот (АлАТ) і субстрат забарвлюється у відповідний колір, інтенсивність якого пропорційна активності ензиму. Інтенсивність забарвлення субстрату визначали за допомогою приладу «Спекол».

Обробку результатів здійснювали у пакеті Statistica 6.0. Вірогідність різниці між вибірками оцінювали за tкритерієм Стьюдента, попередньо перевіривши нормальність їх розподілу. Розбіжності вважали вірогідними за $\mathrm{P}<0,05$.

\section{Результати та їх обговорення}

Ензими - біологічні каталізатори, що прискорюють метаболічні процеси у цитоплазмі клітин. Вони безперервно синтезуються у клітинах і проникають у кров'яне русло. Для ензимів притаманна локалізація у відповідних клітинах та їх структурних елементах (цитоплазмі, мітохондріях, ядрі). За надмірної проникності клітинних мембран ензими надходять у кров і створюють у ній підвищену активність (гіперензимемію). Дослідження активності ензимів у сироватці крові має велике діагностичне та прогностичне значення за різних патологічних станів 
структури паренхіматозних органів. За наявності в організмі патологічного процесу у крові ссавців і птахів змінюється якісний та кількісний склад ензимів, що відображають інтенсивність і спрямованість розвитку патології.

Результати досліджень активності амінотрансфераз щурів за оксидаційного стресу та за дії ліпосомального препарату наведені на рисунках 1-3. Після розвитку оксидаційного стресу у щурів, викликаного введенням тетрахлоретану (дослідна група 1), активність амінотрансфераз дещо відрізнялася від контрольної групи щурів. Це зумовлено збільшенням проникності клітинних мембран гепатоцитів та мітохондріальних мембран і надходженням внутрішньоклітинних ензимів у кров'яне русло.

На другу добу досліду у тварин першої дослідної групи (Д, , яким уводили внутрішньом'язово 50\% тетрахлорметан у дозі 0,25 мл на 100 г маси тіла) зареєстровано зростання у сироватці крові активності аспартатамінотрансфераз (АсАТ) у 2,5 раза (рис. 1), аланінамінотрансфераз (АлАТ) - удвічі (рис. 2) відносно контролю. Ці показники активності амітрансфераз у першій дослідній групі залишалися високими на 5-ту та 10-ту добу досліджень. На 14-ту добу у першій дослідній групі показники активності аспартатамінотрансфераз і аланінамінотрансфераз дещо знизилися, проте були вищими за показники контрольної групи тварин (відповідно АсАТ - на 93\%, АлАТ - на 81\%). Досить показова величина коефіцієнта АсАТ/АлАТ на другу добу досліджень у першої дослідної групи тварин $(3,52 \pm 0,06$ проти контролю 2,72 $\pm 0,04, \mathrm{P}<0,05)$. Це вказує на те, що активність АсАТ вища за активність АлАТ. На 14-ту добу досліджень цей показник залишався високим $(2,89 \pm 0,05$ проти контролю $2,72 \pm 0,04, \mathrm{P}<$ $0,05)$, що на 9\% вище контрольних показників.

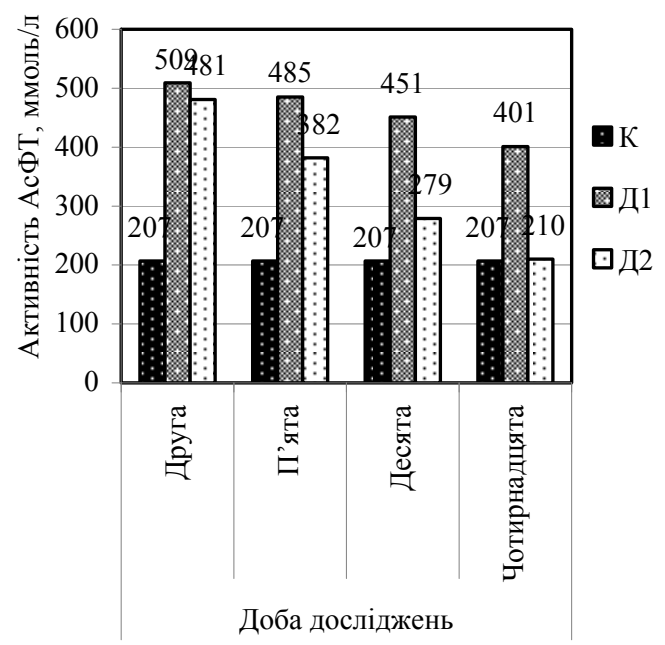

Рис. 1. Активність АсАТ сироватки крові щурів за оксидаційного стресу та за дії ліпосомального препарату: $К$ - контроль, Д1 - хворі, Д2 - ліковані

За оксидаційного стресу та дії ліпосомального препарату у щурів другої дослідної групи (Д2) на другу добу досліджень встановлено вірогідне зростання АсАТ у 2,3 раза (рис. 1), АлАТ - у 2,1 раза (рис. 2) відносно контролю, а величина коефіцієнта АсАТ/АлАТ у вказаний період досліду була вищою на 11,5\% порівняно з показниками клінічно здорових щурів (рис. 3).
Вірогідні зміни зниження показників АсАТ та АлАТ за умов оксидаційного стресу та за дії ліпосомального препарату у сироватці крові щурів відмічаємо на п'яту добу досліджень. Показник АсАТ сироватки крові щурів першої дослідної групи за умов оксидаційного стресу становив 485,3 $\pm 2,1$ ммоль/л, тоді як у контрольної групи тварин він дорівнював 207,3 $\pm 3,0$ ммоль/л $(\mathrm{P}<0,05)$. Показник АлАТ на даний період часу становив 141,2 \pm 6,2 проти 76,2 \pm 4,5 ммоль/л контрольної групи тварин. Зниження показників амінотрансфераз за оксидаційного стресу та за дії ліпосомального препарату у сироватці крові щурів відмічаємо на 10-ту добу досліджень. Показники АсАТ і АлАТ порівняно із показниками другої доби досліджень $(278,8 \pm 1,8$ і 95,7 $\pm 1,7$ ммоль/л) у контрольної групи тварин були відповідно нижчі (207,3 \pm 3,0 і 76,2 \pm 4,5 ммоль/л), що вказує на поступову нормалізацію амінотрансфераз у сироватки крові за оксидаційного стресу та за дії ліпосомального препарату.

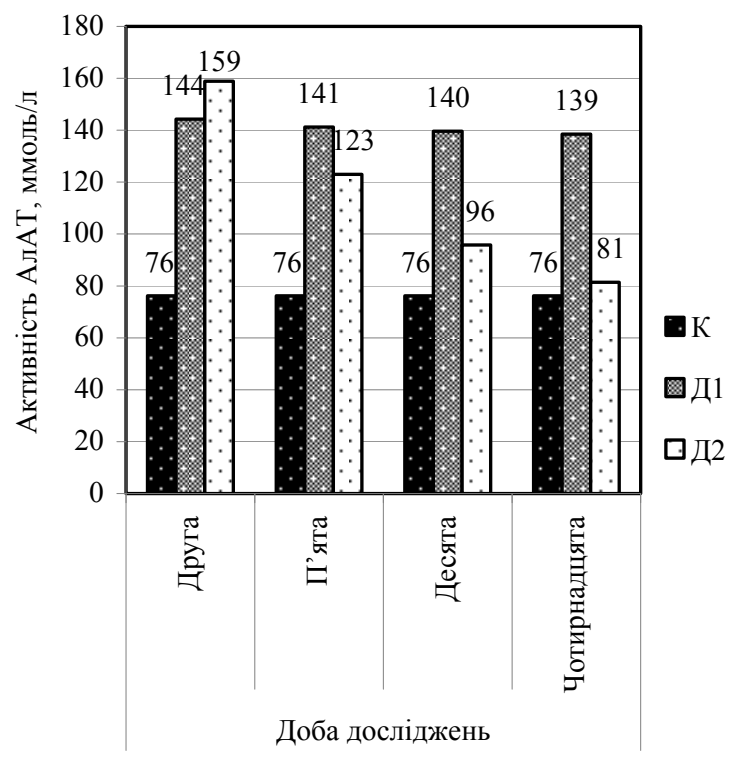

Рис. 2. Активність АлАТ сироватки крові щурів за оксидаційного стресу та за дії ліпосомального препарату: К - контроль, Д1 - хворі, Д2 - ліковані

На 14-ту добу досліджень за оксидаційного стресу та за дії ліпосомального препарату у щурів другої дослідної групи спостерігаємо нормалізацію показників активності амінотрансфераз. Показники АсАТ, АлАТ і коефіцієнт АсАТ/АлАТ порівняно 3 контрольною групою тварин перебувають у межах нормальних величин.

На основі наших досліджень установлено позитивну дію ліпосомального препарату на організм щурів, які були інтоксиковані тетрахлорметаном, що проявляється нормалізацією активності амінотрансфераз у сироватці крові щурів. Низка авторів (Chen et al., 2000; Usha et al., 2007; Saba et al., 2010) зазначають, що токсична дія тетрахлорметану на печінку також супроводжується порушенням іiі функціонального стану, що характеризується накопиченням амінотрансфераз у сироватці крові лабораторних тварин. За літературними даними (Wolf, 1999; Sato et al., 1999; Longo et al., 2007; Morita et al., 2009), підвищення активності даних ензимів після ураження печінки корелює зі ступенем деструкції гепатоцитів. 


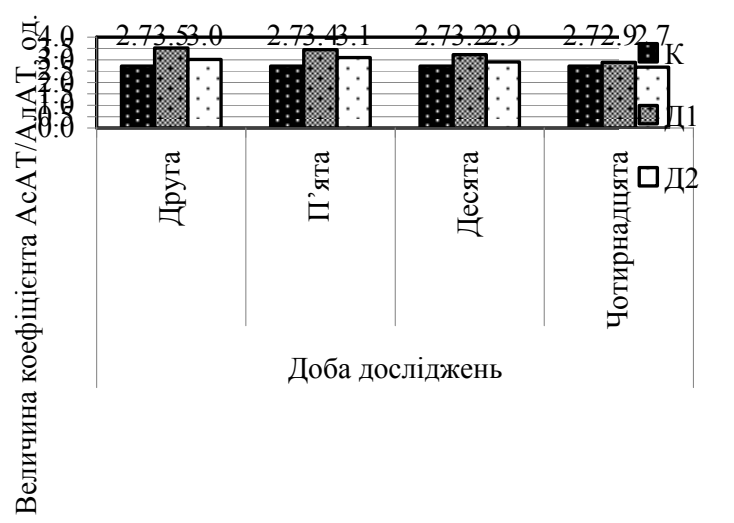

Рис. 3. Коефіціснт АсАТ/АлАТ сироватки крові щурів за оксидаційного стресу та за дії ліпосомального препарату: $К$ - контроль, Д1 - хворі, Д2 - ліковані

Окремі науковці (Wolf, 1999; Cherkashina and Petrenko, 2006; Morita et al., 2009) вважають, що показники активності ензимів у сироватці крові не завжди об'єктивно відображають функціональний і морфологічний стани печінки. Адже амінотрансферази можуть проникати у кров 3 інших органів (особливо з міокарда) у разі виникнення інфаркту. Частковим джерелом надходження амінотрансфераз у сироватку крові після запальних процесів є лейкоцити, що руйнуються у вогнищі запалення, адже в лейкоцитах досить високий рівень амінотрансфераз. Проте більшість науковців (Calabrese et al., 2006; Longo et al., 2007; Usha et al., 2007) у ветеринарії та медицині пропонують визначення активності амінотрансфераз у сироватці крові застосовувати як чутливий тест на проникність мембран гепатоцитів у випадку ураження печінки екзогенними або ендогенними токсинами. Як зазначають клініцисти, висока активність АсАТ і АлАТ у сироватці крові відіграє діагностичну роль за виникнення гострого гепатиту тому, що характеризується високою чутливістю навіть за безсимптомного або легкого перебігу токсикозу. Після виникнення гепатитів активність АлАТ у сироватці крові підвищується раніше і більшою мірою, ніж активність AсAT (Sato et al., 1999; Vyshtakaliuk et al., 2015).

Ми вважаємо, що амінотрансферазна гіперензимемія у сироватці крові хворих тварин настала внаслідок дії на печінку тетрахлорметану, який діє деструктивно на фосфоліпіди клітинних мембран. Це зумовлює збільшення їх проникності та вивільнення амінотрансфераз із гепатоцитів у кров'яне русло. Швидшу нормалізацію активності амінотрансфераз у сироватці крові встановлено у щурів, яких за інтоксикації тетрахлоретаном лікували ліпосомальним препаратом, що у своєму складі містить розторопшу та володіє гепатопротекторною дією.

\section{Висновки}

У разі отруєння щурів тетрахлорметаном у печінці відбуваються глибокі деструктивні зміни клітинних оболонок гепатоцитів та мітохондріальних мембрам, що проявляється підвищеною активністю ензимів аміно- трансфераз: другу добу досліджень відмічали підвищення активності АсАТ у 2,5 раза, АлАТ - удвічі, а коефіцієнта АсАТ/АлАТ - на 30\% порівняно з контролем. На 14-ту добу досліджень активність ферментів була вищою за показники контрольної групи тварин: АсАТ і АлАТ - відповідно на 93\% і 81\%, коефіцієнт становив 2,89 $\pm 0,05$ проти контролю 2,72 $\pm 0,04$.

За умов застосування щурам ліпосомального препарату за оксидаційного стресу у сироватці крові настає нормалізація активності амінотрансфераз. На 14-ту добу показники АсАТ, АлАТ і коефіцієнт АсАТ/АлАТ були в межах фізіологічних величин, що вказує на відновлення проникності клітинних оболонок гепатоцитів та мітохондріальних мембран у гепатоцитах печінки. Перспектива подальших досліджень - оцінка показників клітинного імунітету крові щурів за оксидаційного стресу та за дії ліпосомального препарату.

\section{Бібліографічні посилання}

Adom, K.K., Sorrells, M.E., Liu, R.H., 2005. Phytochemicals and antioxidant activity of milled fractions of different wheat varieties. J. Agric. Food Chem. 53(6), 2297-2306.

Calabrese, E., Leonard, D., Zhao Xiaoqiang, 1999. Role of tissue repair in carbon tetrachloride hepatotoxicity in male and female Sprague-Dawley and Wistar rats. Int. J. Toxicol. 15, 62-69.

Chen, W., Kennedy, D.O., Kojima, A., Matsui-Yuasa, I., 2000. Polyamines and thiols in the cytoprotective effect of L-cysteine and L-methionine on carbon tetrachlorideinduced hepatotoxicity. Amino Acids 18(4), 319-327.

Cherkashina, D.V., Petrenko, A.Y., 2006. Hepatoprotective effect of fetal tissue cytosol and its thermostable fraction in rats with carbon tetrachloride-induced hepatitis. B. Exp. Biol. Med. 141(4), 544-547.

Devanto, V., Wu, X., Liu, R.H., 2002. Processed sweet corn has higher antioxidant activity. J. Agric. Food Chem. 50(17), 4959-4964.

Kornyat, S.B., Sharan, M.M., Andrushko, O.B., Yaremchuk, I.M., 2015. Metabolichnyj profil' krovi koriv za likuvannja hipofunkciji jajechnykiv hormonal'nymy ta fitopreparatamy [Metabolic profile of cow blood under the treatment of ovaries hypofunction by hormonal and phyto-preparations]. Biological Bulletin of Bogdan Chmelnitskiy Melitopol State Pedagogical University 5(2), 103-111 (in Ukrainian).

Liu, R.H., Finley, J., 2005. Potential cell culture models for antioxidants research. J. Agric. Food Chem. 53(10), 4311-4314.

Longo, V., Chirulli, V., Gervasi, P.G., Nencioni, S., Pellegrini, M., 2007. Lisosan G, a powder of grain, does not interfer with the drug metabolizing enzymes and has a protective role on carbon tetrachloride-induced hepatotoxicity. Biotechnol. Lett. 29(8), 1155-1159.

Meyers, K.K., Watkins, C.B., Pritts, M.P., Liu, R.H., 2003. Antioxidant and antiproliferative activities of strawberries. J. Agric. Food Chem. 51(23), 6887-6892.

Morita, M., Akai, S., Hosomi, H., Tsuneyama, K., Nakajima, M., Yokoi, T., 2009. Drug-induced hepato-toxicity test using gamma-glutamylcysteine synthetase knockdown rat. Toxicol. Lett. 189(2), 159-165.

Rababah, T.M., Ereifej, K.I., Howard, L., 2014. Effect of ascorbic acid and dehydration on concentrations of total phenolics, antioxidant capacity, anthocyanins, and color in fruits. J. Agric. Food Chem. 53(11), 4444-4447.

Saba, A.B., Oyagbemi, A.A., Azeez, O.I., 2010. Amelioration of carbon tetrachloride-induced hepatotoxicity and haemotox- 
icity by aqueous leaf extract of Cnidoscolus aconitifolius in rats. Nig. J. Physiol. Sci. 25, 139-147.

Sato, S., Dai, W., Liu, X.-L., Asano, G., 1999. The protective effect of hepatocyte growth-promoting factor (pHGF) against carbon tetrachloride-induced acute liver injury in rats: An ultrastructural study. Med. Electron Microsc. 32(3), 184-192.

Usha, K., Mary Kasturi, G., Hemalatha, P., 2007. Hepatoprotective effect of Hygrophila spinosa and Cassia occidentalis on carbon tetrachloride induced liver damage in experimental rats. Indian J. Clin. Biochem. 22(2), 132-135.

Vlizlo, V.V., Fedoruk, R.S., Ratych, I.B., 2012. Laboratorni metody doslidzhen u biolohiyi, tvarynnytstvi ta veterynarniy me- dytsyni [Laboratory methods of investigation in biology, stock-breeding and veterinary]. Spolom, Lviv (in Ukrainian).

Vyshtakaliuk, A.B., Nazarov, N.G., Porfiriev, A.G., Zueva, I.V., Minnechanova, O.A., Mayatina, O.V., Reznik, V.S., Zobov, V.V., Nicolskyi, E.E., 2015. The influence of the Xymedon preparation (Hydroxyethyldimethyldihydropyrimidine) on the rat liver recovery under toxic damage induced by carbon tetrachloride. Biochemistry, Biophysics and Molecular Biology 462(1), 143-146.

Wolf, P.L., 1999. Biochemical diagnosis of liver disease. Indian J. Clin. Biochem. 14(1), 59-90.

Надійшла до редколегї 19.02.2016 